\title{
Factors Affecting the Capital Structure of Pharmaceutical - Medical Companies Listed on Vietnam's Stock Exchanges
}

\author{
Nguyen Thi Ha THANH ${ }^{1}$, Ho Linh TRANG ${ }^{2 *}$ \\ ${ }^{1}$ Faculty of Banking and Finance, Foreign Trade University, Hanoi, Vietnam \\ ${ }^{2}$ Newcastle University, Newcastle, UK \\ *Corresponding author: 1.t.ho2@newcastle.ac.uk
}

\begin{abstract}
This paper investigates the determinants of the capital structure of pharmaceutical - medical companies listed on the Hanoi Stock Exchange (HNX) and Ho Chi Minh Stock Exchange (HOSE) over the period of 2016 - 2020 by deploying the capital structure theories combining Modigliani and Miller's capital structure theory, trade-off theory, pecking-order theory, and agency cost theory. We then apply Pooled OLS Model, Fixed Effects Model (FEM), Random Effects Model (REM) and Feasible Generalized Least Square Model (FGLS) on panel data collected from financial statements of 23 pharmaceutical - medical listed companies. The empirical results indicate that profitability, tangible assets, firm size and liquidity have negative correlation with capital structure while growth opportunities has positive effect on capital structure. In contrast, the impact of firm age and pluralist executives on firms' debt ratio are found to have no statistical meaning. In contrast, firm age and pluralist executives do not have statistical significance. Furthermore, the research results also discuss implications and give recommendations for investment activities and corporate policymaking of listed pharmaceutical - medical companies.
\end{abstract}

\section{Research purpose:}

In this paper, we utilize the traditional capital structure theories comprise Modigliani and Miller's capital structure theory, Trade-off theory, Pecking-order theory, and Agency cost theory to explore factors affecting the capital structure of 23 pharmaceutical - medical companies listed on the Hanoi Stock Exchange (HNX) and Ho Chi Minh Stock Exchange (HOSE) over the period of $2016-2020$

Research motivation:

Vietnam's economy has changed a lot in recent years, especially in the context of the COVID-19 pandemic. This has a great influence on the choice of enterprise capital structure today. During this period, the level of debt usage of the pharmaceutical - medical industry increases to finance the fight against the epidemic, therefore pharmaceutical and medical enterprises are always alarmed about the debt-to-total asset ratio.

Research design, approach and method:

This study identifies the determinants affecting the capital structure of listed pharmaceutical medical enterprises on Hanoi Stock Exchange and Ho Chi Minh City Stock Exchange by using the Pooled OLS, FEM, REM and FGLS regression method. Data is collected from financial statements and annual reports of 23 listed pharmaceutical medical firms during the period from 2016 to 2020. The regression model is used to determine the impact of seven explanatory variables including profitability, tangible asset, firm size, growth opportunities, liquidity, firm age and pluralist executives on the ratio of total debt to total assets.

Main findings:

Research results reveal that profitability, tangible assets, firm size and liquidity have a negative correlation with capital structure. In contrast, growth opportunities have a positive impact on capital structure while firm age and pluralist executives do not correlate with debt ratio.

\section{Practical/managerial implications:}

The study systematizes a number of traditional theories on capital structure and identifies the determinants of the capital structure of 23 pharmaceutical - medical enterprises listed on Vietnam's Stock Exchange as well as measuring the significance level of each factor to the capital structure.

Keywords: Capital structure, debt ratio, pharmaceutical-medical listed firms, stock exchanges 


\section{INTRODUCTION}

Whether there is an optimal financial structure for every business and if so, how it affects the value of the business has been the subject of debate in the financial community for decades, (Modigliani and Miller, 1958) found that under perfect capital market conditions with no taxes, no transaction costs, no asymmetric information, and homogeneous market expectations, firm value is independent of capital structure. The above work has contributed to the formation of modern capital structure theory.

The capital structure changes depending on the characteristics of each enterprise, the area in which it operates, and the impact of macroeconomic volatility of the economy, culture, and religion. From the relationship between the determinants affecting the use of the financial leverage and the capital structure, we can assess whether the decision to use the loan or the business's equity is appropriate or not, then propose solutions to enhance the efficiency of using financial leverage, maximizing asset value for businesses.

Vietnam's economic context in recent years has had many changes, especially when the COVID-19 pandemic has been complicated, leading to a great influence on the capital structures of firms in the pharmaceutical - medical sector. The economy has been growing recently, citizens' incomes are becoming better. However, the Vietnamese population is getting older, and health problems arise from the environment and industrialization, especially from the COVID-19 pandemic. It results in an increased willingness to pay for medical services, therefore, leading to the inevitable development of Vietnam's pharmaceutical industry.

Therefore, the aim of this study is to identify which factors and their affecting level to the capital structure of pharmaceutical and medical listed firms in the Vietnamese stock market, thereby helping financial planners, as well as firms, have a suitable view on opting for the optimal capital structures.

\section{LITERATURE REVIEW}

\subsection{Theories of Capital Structure}

\section{Capital structure theory of Modigliani and Miller (1958)}

The initial study for modern capital structure studies was introduced by (Modigliani and Miller, 1958). Modigliani and Miller studied the case in which firms operating in a tax-free environment. They assumed that the capital market was perfect, the firm's value is not dependent on the capital structure because the value of a firm must depend on the present value of its operations.

(Modigliani and Miller, 1963) produced a follow-up study that eliminated the hypothesis of corporate income tax. In this case, the higher the use of debt, the greater the value of the business and the maximum increase when the company is financed $100 \%$ of its debt with the theory's assumptions comprise no corporate income tax, no transaction costs, bankruptcy costs and financial hardship costs, individuals and institutions can borrow money equally, the capital market is perfect, and no single investor has a significant influence on the price of a security.

\section{Trade-off theory}

(Kraus and Litzenberger, 1973) developed the trade-off theory of capital structure. The trade-off theory refers to the idea that a firm will choose how much debt and how much equity to finance in order to balance costs and benefits. According to this theory, managers believe they will find an optimal capital structure that maximizes firm value.

The target capital structure is the point at which the benefits from increasing debt are offset by the additional costs of financial distress. In most cases, financial distress leads to bankruptcy. Therefore, businesses should only borrow to the extent that the tax benefit from an additional dollar of borrowed capital equals the additional financial distress costs from borrowing the capital.

The trade-off theory assumes that the target debt ratio can be different among firms. Companies that have certain tangible assets and high profitability have higher debt ratios and vice versa. Thus, this theory shows that tangible fixed assets ratio, profitability, tax shield, and financial risk affect capital structure.

\section{Pecking-order theory}

According to (Donaldson, 1961), instead of issuing more shares, the use of retained earnings of the enterprise will be a major channel to increase the capital of the enterprise. Agreeing with the same view, (Myers and Majluf, 1984) continued to develop Donaldson's research and the pecking order theory was introduced. It is hypothesized that management based on asymmetric information affects the investment and financing decisions of the firm.

This theory helps to explain why more profitable firms tend to have low debt ratios (which the trade-off theory cannot present), and less fortunate firms issue debt because they do not have enough capital to fund projects and because debt ranks first in the pecking order of external financing.

\section{Agency theory}

Agency theory (Jensen and Meckling, 1976) recognizes the existence of an optimal capital structure for the firm, because of the presence of agency costs. Agency costs incurred when the agent acts or makes decisions on behalf of the principal. Agency costs often arise during core inefficiencies, discontent and business disruptions, such as conflicts of interest between shareholders and managers. Agency costs are divided into two categories: Agency costs arising from conflicts between shareholders and bondholders (agency costs of debt); 
and agency costs arise conflicts between shareholders and managers (agency costs of equity).

\subsection{Previous studies}

(Titman and Wessels, 1988) determined the factors affecting the choice of capital structure of 469 companies listed on the US stock exchange from 1974 to 1982 and found that short-term debt ratio has a negative correlation with firm size, profitability has a negative correlation with debt ratio measured at market prices. Small businesses tend to use more short-term debt than large companies, reflecting the high costs that small firms face when issuing long-term financial instruments. The business characteristics have a negative relationship with the debt ratio. The remaining factors such as tangible assets, non-debt tax shield, business risk, growth opportunities, industry dummy do not correlate with debt ratio.

(Huang and Song, 2006) studied the determinants of capital structure of more than 1000 Chinese companies from 1994 to 2000. Research results are as follows: Firm size, non-debt tax shield, and tangible assets increase in the same direction as leverage; Leverage increases inversely with profitability and has a relationship with the industry; Equity structure affects leverage.

(J. Chen and Strange, 2005) identified the determinants of the capital structure of listed firms on the Shanghai Stock Exchange and Shenzhen Stock Exchange in 2003. The authors explored that profitability has a negative impact on the capital structure while size, risk, and firm age positively impact the debt ratio. In addition, intangible assets and growth opportunity do not have statistically significant effects. (Sheikh and Wang, 2011) reported that four independent variables, including profitability, liquidity, and tangibility, have a negative impact on the debt ratio, while the firm size has a positive relationship with the debt ratio.

The research of (Abor, 2007) analyzed 22 listed firms in the Ghanaian Stock Exchange during 1998-2003 to find out the impact of corporate governance on capital structure. Research results showed that capital structure has a positive relationship with board size, CEO duality, and board composition. The results also pointed out that CEO tenure has a negative impact on the leverage, but this relationship is insignificant.

In Vietnam, the number of research works mainly focus on the factors affecting the capital structure of state-owned enterprises and enterprises listed on the stock exchange. The results of these studies have made significant contributions in explaining the theoretical model of capital structure in enterprises in Vietnam and identifying the factors affecting the capital structure of enterprises. Specifically, some typical research results in the past period are as follows:

The study of (Nguyen and Ramachandran, 2006) was carried out to find the factors affecting capital structure of Vietnamese SMEs during the period 1998-2001.
Empirical results showed the strong positive influence of growth, business risk, firm size, networking, and relationships with banks and the negative impact of tangibility on the capital structure of SMEs in Vietnam Furthermore, profitability seems to have no significant relationship with the capital structure of Vietnamese SMEs.

(Anh, 2010) applied the path analysis method using data from financial statements for three years (2007-2009) of 428 listed companies on the stock market to identify the factors that affect the economic structure and financial performance. The research results show that the firm size factor has a positive relationship $(+)$ with the financial system. In contrast, the factors such as business efficiency, business risk, and asset structure have a negative association (-) for financial structure.

(Minh and Dung, 2015) examined an analysis of multiple factors affecting the capital structure of Vietnam's real estate enterprises based on data of 47 listed firms on HOSE and HNX over the period of 2008-2013 and found that growth rate is positively related with leverage ratio. In contrast, profitability and risk are proved to have negative impacts on the company's debt ratio while firm size, tangible assets, and liquidity have no impacts on leverage ratio.

(Vo, 2017) employed data from listed firms' data on Ho Chi Minh City stock exchange from 2006 to 2015 and found that the growth opportunity has positive relationship but not significant for long-term and short-term leverage while tangible assets have a positive and significant influence on long-term debt ratio but are negative in explaining short-term leverage. Firm size is positive and significant when used to explain long-term debt but has opposite relationship with short-term debt.

However, these studies have inconsistent conclusions. Therefore, more research is needed to supplement the theory of the capital structure of enterprises in different fields in the Vietnam market in general and in the pharmaceutical industry in particular.

\section{HYPOTHESES, RESEARCH METHODOLOGY AND REGRESSION MODEI}

\subsection{Hypotheses}

Based on the theories of capital structure and from previous researches, this study synthesizes and proposes hypotheses to clarify the impact of the relationship between independent variables and debt ratio. Specifically:

H1: Profitability (PROF) has a negative relationship (-) with the debt ratio

Profitability is reflected in billion return on total assets (ROA). Profitability has both a positive effect when analyzed according to the trade-off theory and an opposite effect when analyzed according to the pecking theory. Experimental studies also give different results, 
however, most studies show that profitability has a negative relationship with the debt ratio of enterprises. The empirical researches supported this opinion including researches of (Titman and Wessels, 1988); (Wald, 1999); (J. Chen and Strange, 2005); (Huang and Song, 2006); (De Jong, Kabir, and Nguyen, 2008); (Saeed, Munir, Lodhi, Riaz, and Iqbal, 2014), (Anh and Huyen, 2015), (Imtiaz, Mahmud, and Mallik, 2016)

\section{H2: Tangible assets (TANG) has a positive relationship} $(+)$ with the debt ratio.

Tangible asset is a variable reflecting the structure of assets of the enterprise, determined by the ratio of fixed assets to total assets of the enterprise. Based on the theory of agency costs and trade-off costs, owning a lot of fixed assets can help businesses get loans more easily because they have collateral. Evidences that Tangible assets has a positive correlation with capital structure were found in (Titman and Wessels, 1988), (Frank and Goyal, 2003), (Anh, 2010), (Saeed et al., 2014), (Huang and Song, 2006).

\section{H3: The size of firms (SIZE) has a positive relationship} (+) with debt ratio.

The size of the firm is measured by the natural logarithm of the total assets of the enterprise. Typically, the larger the company, the more debt it will be able to borrow, since large companies often diversify their business lines and asymmetric information risk is lower than small companies. According to agency cost theory, large firms tend to use more debt, this relationship is explained by the information asymmetry between shareholders and managers, when managers take control of the business over which shareholders have no control. It was supported by plenty of empirical studies in the world including (J. Chen and Strange, 2005), (Nguyen and Ramachandran, 2006), (Abor, 2007), (Saeed et al., 2014), (Anh and Huyen, 2015), (Imtiaz et al., 2016).

H4: Growth opportunity (GRO) has a positive relationship (+) with debt ratio

This indicator is computed by dividing the difference in net sales between the following year and the previous year by the previous year's net sales. When the business is in the growth stage, investors' confidence in the business will be high, so the ability to access capital from outside is greater, while the business needs funding for its assets.

According to the pecking order theory, good business growth means that there is a large demand for loans, when retained earnings are not enough to meet operations, they will prioritize the choice of loans to increase the debt ratio. The empirical studies that supported this opinion include (Vo, 2017), (Minh and Dung, 2015), (Nguyen and Ramachandran, 2006).

H5: Liquidity (LIQ) has a negative relationship (-) with debt ratio

For enterprises, the role of short-term solvency is very important in creating the value of enterprises. However, if the business continues to improve its short-term solvency, it may have too many short-term assets and it may not be able to improve profitability; or even profits decline and it will reduce the value of the business. (Vo, 2017) pointed out that liquidity is one of the important issues determining the success of Vietnamese enterprises. The study shows an inverse relationship between liquidity and short-term leverage of enterprises. (De Jong et al., 2008) and (Saeed et al., 2014) also investigated a significant negative impact of liquidity on the firm leverage.

H6: Firm age (AGE) has a negative relationship (-) with debt ratio

Typically, when a business has a high number of years of listing, the reputation of that business is built more firmly if the business operation is effective. This creates a solidity in the process of trading and consuming products. Therefore, the older an enterprise is, the more trustworthy information about the business on the market, because this will create favorable conditions for investors to easily access capital sources rather than borrow on the market. On the other hand, the life of an enterprise usually has four stages, the old enterprise will be in the saturation stage, this stage has grown to the peak, the shortage of capital will put less pressure on the managers and firms tend to borrow less. Researches of (Hall, Hutchinson, and Michaelas, 2000); (Kieschnick and Moussawi, 2018), (J. Chen and Strange, 2005) supported this idea.

\section{H7: Pluralist executives have a negative influence (-) on debt ratio}

According to agency theory, when the CEO and the chairman are independent, the managers can run the company in the most objective way, but it can affect the interests of shareholders. On the other hand, if the CEO is the chairman, the decision of the CEO duality will have a direct influence on the company's loan decision. Firms often use less debt to avoid the risk of bankruptcy. (Fosberg, 2004) found a negative relationship between pluralist executives and leverage ratio. However, according to (Abor, 2007), there is a positive relationship between pluralist executives and the use of debt while (Jaradat, 2015) points out that there is no significant impact of CEO duality on capital structure.

Table 1. Summaries of research hypotheses and predicted signs

\begin{tabular}{|l|l|l|l|}
\hline Hypothesis & Determinant & $\begin{array}{l}\text { Predicted } \\
\text { sign }\end{array}$ & Source \\
\hline H1 & Profitability & $(-)$ & (Titman and \\
& (PROF) & & Wessels, \\
& & & 1988); (J. Chen \\
& & and Strange, \\
& & 2005); (Huang \\
& & and Song, \\
& & 2006); (De \\
& & & Jong et al., \\
& & 2008), (Anh \\
& & & and Huyen, \\
\hline
\end{tabular}




\begin{tabular}{|c|c|c|c|}
\hline & & & 2015) \\
\hline $\mathrm{H} 2$ & $\begin{array}{l}\text { Tangible } \\
\text { assets } \\
\text { (TANG) }\end{array}$ & $(+)$ & $\begin{array}{l}\text { (Titman and } \\
\text { Wessels, } \\
\text { 1988); (Saeed } \\
\text { et al., 2014); } \\
\text { (Frank and } \\
\text { Goyal, 2003); } \\
\text { (Huang and } \\
\text { Song, 2006) }\end{array}$ \\
\hline $\mathrm{H} 3$ & $\begin{array}{l}\text { Firm size } \\
\text { (SIZE) }\end{array}$ & $(+)$ & $\begin{array}{l}\text { (J. Chen and } \\
\text { Strange, 2005); } \\
\text { (Nguyen and } \\
\text { Ramachandran, } \\
\text { 2006); (Abor, } \\
\text { 2007); (Saeed } \\
\text { et al., 2014); } \\
\text { (Imtiaz et al., } \\
\text { 2016). }\end{array}$ \\
\hline $\mathrm{H} 4$ & $\begin{array}{l}\text { Growth } \\
\text { opportunity } \\
\text { (GRO) }\end{array}$ & $(+)$ & $\begin{array}{l}\text { (Vo, 2017); } \\
\text { (Minh and } \\
\text { Dung, 2015); } \\
\text { (Nguyen and } \\
\text { Ramachandran, } \\
\text { 2006). }\end{array}$ \\
\hline H5 & $\begin{array}{l}\text { Liquidity } \\
\text { (LIQ) }\end{array}$ & $(-)$ & $\begin{array}{l}\text { (De Jong et al., } \\
\text { 2008); (Saeed } \\
\text { et al., 2014) }\end{array}$ \\
\hline H6 & $\begin{array}{l}\text { Firm age } \\
\text { (AGE) }\end{array}$ & $(-)$ & $\begin{array}{l}\text { (Kieschnick } \\
\text { and Moussawi, } \\
\text { 2018); (J. Chen } \\
\text { and Strange, } \\
\text { 2005) }\end{array}$ \\
\hline $\mathrm{H} 7$ & $\begin{array}{l}\text { Pluralist } \\
\text { executives } \\
\text { (PLU) }\end{array}$ & $(-)$ & $\begin{array}{l}\text { (Fosberg, } \\
2004)\end{array}$ \\
\hline
\end{tabular}

Source: Authors' compilation

\subsection{Research data and methodology}

The data used in this study is panel data collected from audited financial statements for 5 years from 2016 to 2020 of 23 medical pharmaceutical companies listed on HOSE, HNX (including 115 observations).

There are 23 pharmaceutical - medical firms listed on Vietnam's stock exchanges, of which 13 pharmaceutical companies are listed on the Ho Chi Minh City Stock Exchange and 10 pharmaceutical companies are listed on the Hanoi Stock Exchange. The data was collected from financial statements these companies during the five-year period from 2016 to 2020 .

The author used Excel to collect data including total asset, total debt, fixed asset, current asset current liability, EBIT and calculate the necessary ratios. To analyze and test the regression model, the paper used the STATA 13.0 software to analyze the data.
Table 2: Dependent variable and independent variables

\begin{tabular}{|c|c|c|}
\hline & Variables & Measurement \\
\hline $\begin{array}{l}\text { Dependent } \\
\text { variable }\end{array}$ & $\begin{array}{l}\mathrm{TD}: \quad \text { Debt } \\
\text { ratio }\end{array}$ & Total debt/ Total assets \\
\hline \multirow{7}{*}{$\begin{array}{l}\text { Independent } \\
\text { variables }\end{array}$} & $\begin{array}{l}\text { PROF: } \\
\text { Profitability }\end{array}$ & EBIT/ Total assets \\
\hline & $\begin{array}{l}\text { TANG: } \\
\text { Tangible } \\
\text { assets }\end{array}$ & $\begin{array}{l}\text { Fixed assets/ Total } \\
\text { assets }\end{array}$ \\
\hline & $\begin{array}{l}\text { SIZE: Firm } \\
\text { size }\end{array}$ & $\begin{array}{l}\text { Logarithm of total } \\
\text { assets }\end{array}$ \\
\hline & $\begin{array}{l}\text { GRO: } \\
\text { Growth } \\
\text { opportunity }\end{array}$ & $\begin{array}{l}\text { Change of percentage } \\
\text { of total assets }\end{array}$ \\
\hline & $\begin{array}{l}\text { LIQ: } \\
\text { Liquidity }\end{array}$ & $\begin{array}{l}\text { Current assets/ Current } \\
\text { liabilities }\end{array}$ \\
\hline & $\begin{array}{l}\text { AGE: Firm } \\
\text { age }\end{array}$ & $\begin{array}{l}\text { The number of years }= \\
\text { present year - year of } \\
\text { listing }\end{array}$ \\
\hline & $\begin{array}{l}\text { PLU: } \\
\text { Pluralist } \\
\text { Executives }\end{array}$ & $\begin{array}{l}1 \text { if the CEO is the } \\
\text { chairman of the Board } \\
\text { of Directors; } \\
0 \text { if the CEO is not the } \\
\text { chairman of the Board } \\
\text { of Directors. }\end{array}$ \\
\hline
\end{tabular}

Source: Authors' compilation

This study uses panel data and deploys three commonly used methods which are Pooled OLS Model, Fixed Effects Model (FEM) and Random Effects Model (REM) to determine the correlation relationship between the variables and the influence of the explanatory variables on the debt ratio of listed companies.

The authors will use quantitative methods to overcome the defects of the model selected as the result for the study. Finally, Feasible Generalized Least Square (FGLS) method is chosen to propose final regression model

\subsection{Regression model}

This paper analyzes a number of determinants affecting capital structure: profitability, tangible assets, firm size, firm age, growth opportunities, liquidity, pluralist executives.

The detailed model is as follows:

TD $=\alpha+\beta_{1}$ PROF $_{t}+\beta_{2}$ TANG $_{t}+\beta_{3}$ SIZE $_{t}$

$+\beta_{4} G R O_{t}+\beta_{5} L I Q_{t}+\beta_{6} A G E_{t}+\beta_{7} P L U_{t}+\varepsilon$

In which:

TD: Dependent variable 
PROF, TANG, SIZE, GRO, LIQ, AGE, PLU: Independent variables

$\alpha$ : Intercept

$\varepsilon:$ random errors

\section{RESULTS OF DATA ANALYSIS}

\subsection{Descriptive statistics of variables}

Table 3. Descriptive statistics of variables

\begin{tabular}{|c|c|c|c|c|c|}
\hline $\begin{array}{l}\text { Variable } \\
\text { s }\end{array}$ & Obs & Mean & $\begin{array}{l}\text { Std. } \\
\text { Dev }\end{array}$ & Min & Max \\
\hline TD & 115 & 0.3942 & $\begin{array}{l}0.216 \\
8\end{array}$ & 0.0484 & 0.9651 \\
\hline PROF & 115 & 0.1001 & $\begin{array}{l}0.089 \\
4\end{array}$ & $\begin{array}{l}-0.131 \\
8\end{array}$ & 0.4245 \\
\hline TANG & 115 & 0.2286 & $\begin{array}{l}0.161 \\
2\end{array}$ & 0.0059 & 0.6622 \\
\hline SIZE & 115 & $\begin{array}{l}27.2945 \\
5\end{array}$ & $\begin{array}{l}1.174 \\
3\end{array}$ & $\begin{array}{l}23.739 \\
8\end{array}$ & $\begin{array}{l}30.470 \\
8\end{array}$ \\
\hline GRO & 115 & 0.3457 & $\begin{array}{l}1.977 \\
7\end{array}$ & $\begin{array}{l}-0.894 \\
8\end{array}$ & $\begin{array}{l}19.336 \\
2\end{array}$ \\
\hline LIQ & 115 & 2.5849 & $\begin{array}{l}1.730 \\
2\end{array}$ & 0.8866 & $\begin{array}{l}13.327 \\
8\end{array}$ \\
\hline AGE & 115 & 7.6435 & $\begin{array}{l}3.855 \\
2\end{array}$ & 0 & 14 \\
\hline PLU & 115 & 0.3478 & $\begin{array}{l}0.478 \\
4\end{array}$ & 0 & 1 \\
\hline
\end{tabular}

Source: Authors' calculation from the STATA 13.0 software

Descriptive statistics show that the ratio of debt to total assets accounts for $39.42 \%$ of studied enterprises. In which, the minimum value of debt ratio (TD) is 0.0484 and the maximum value is 0.9651 . The profitability (PROF) of pharmaceutical - medical enterprises in the research period had an average value of $10.01 \%$, with the lowest value being $-13.18 \%$ and the largest being $42.45 \%$. The ratio of fixed assets to total assets (TANG) of pharmaceutical - medical firms in the sample has the largest value of $66.22 \%$ while the lowest is $0.59 \%$. The mean of fixed asset ratio of the sample is $22.86 \%$ with a standard deviation of 0.1612 . The firm size (SIZE) is the logarithm of the average total assets, which is 27.29455 units, the highest is 30.4708 units, and the lowest is 23.7398 units which illustrate that the size of the enterprise is very diverse. The average revenue growth rate of pharmaceutical - medical enterprises in the sample is $34.57 \%$. The lowest growth opportunities rate (GRO) of $-89.48 \%$ shows that enterprises operate at a loss while the highest revenue growth rate is $1933.62 \%$. Current assets over current liabilities (LIQ) averaged $258.49 \%$, the highest is $1332.78 \%$, and the lowest is $88.66 \%$. The liquidity of these listed firms is significantly increased, which means these firms have an appropriate ratio between current assets and current liabilities. The firm age (AGE) averaged 7.6 years. Firms with the highest years of operation have been listed for 14 years.

\subsection{Correlation matrix}

Table 4: Correlation matrix of research variables

\begin{tabular}{lllllllll}
\hline & TD & $\begin{array}{l}\text { PRO } \\
\text { F }\end{array}$ & $\begin{array}{l}\text { TAN } \\
\text { G }\end{array}$ & SIZE & $\begin{array}{l}\text { GR } \\
\mathrm{O}\end{array}$ & LIQ & AGE & $\begin{array}{l}\text { PL } \\
\mathrm{U}\end{array}$ \\
\hline TD & 1 & & & & & & & \\
PR & -0.48 & 1 & & & & & & \\
OF & 37 & & & & & & & \\
TA & -0.11 & -0.12 & 1 & & & & & \\
NG & 28 & 46 & & & & & & \\
SIZ & -0.02 & 0.04 & -0.47 & 1 & & & & \\
E & 45 & 43 & 05 & & & & & \\
GR & -0.14 & -0.02 & -0.17 & 0.06 & 1 & & & \\
O & 99 & 51 & 54 & 89 & & & & \\
LIQ & -0.66 & 0.38 & -0.26 & 0.14 & 0.56 & 1 & & \\
& 64 & 83 & 31 & 92 & 09 & & & \\
AG & -0.13 & -0.05 & 0.03 & 0.12 & 0.03 & 0.15 & 1 & \\
E & 18 & 42 & 28 & 64 & 20 & 00 & & \\
\hline PL & -0.10 & 0.14 & 0.02 & -0.18 & 0.16 & 0.16 & -0.36 & 1 \\
U & 67 & 40 & 07 & 55 & 08 & 08 & 98 & \\
\hline Source: Authors & calculation & from & the & STATA & 13.0 \\
Software & & & & & & &
\end{tabular}

According to table 4, the debt ratio was negatively correlated with all 7 independent variables. It indicates that firms with higher profitability, tangible asset, size, growth opportunity, liquidity, age are less interested to use more debt as part of their capital structure.

Among the independent variables, the correlation coefficient ranges from 0.025 to 0.67 , so in general with the significance level of $5 \%$, there is a relationship between the independent variables and dependent variables. TD and LIQ have the strongest correlation with each other because the absolute value of the correlation coefficient is 0.67 . To ensure the effectiveness of the research, the author carried out the multicollinearity test by examining the VIF. VIF value is from 1.35 to 1.07 which is smaller than 10. Accroding to (Gujarati, Porter, and Gunasekar, 2012), the regression model does not have multicollinearity.

\subsection{Empirical results}

Table 5: Result of regression models

\begin{tabular}{lllll}
\hline & $\begin{array}{l}\text { Pooled } \\
\text { OLS }\end{array}$ & FEM & REM & FGLS \\
\hline PROF & $-0.507 * *$ & $-0.2598^{*}$ & $-0.4216^{* * * *}$ & $-0.4619 * * *$ \\
TANG & $-0.4568^{* * *}$ & 0.1243 & -0.0979 & $-0.0433 * * *$ \\
SIZE & -0.013 & -0.0364 & -0.0281 & $-0.0298 * * *$ \\
GRO & 0.0259 & 0.0069 & 0.0091 & $0.0335 * * *$ \\
LIQ & $-0.0996 * * *$ & $-0.0299 * * *$ & $-0.0468 * * *$ & $-0.0977 * * *$ \\
AGE & -0.0006 & -0.0022 & -0.0037 & 0.0035 \\
\hline
\end{tabular}




\begin{tabular}{lllll}
\hline PLU & 0.0012 & -0.0331 & -0.0295 & 0.0155 \\
Cons & $1.1594 * *$ & $1.489 * *$ & $1.3844^{* * *}$ & $1.5625^{* * *}$ \\
\hline
\end{tabular}

Source: Authors' calculation from the STATA 13.0 software

$$
\text { (Note: } * p<0.01, * * p<0.05, * * * p<0.1 \text { ) }
$$

The regression results of Table 5 show that, with the dependent variable TD, R2 of 3 models Pooled OLS, FEM, REM are $63.69 \%, 27.91 \%$ and $23.34 \%$. This shows that the variables in the research model can explain $63.69 \%, 27.91 \%$ and $23.34 \%$ of TD dependent variables.

However, when estimating according to the Pooled OLS model, the model does not reflect the characteristics of each enterprise. Therefore, the study conducted a test to select FEM or REM models as suitable models. Hausman test gives p-value: Prob $>$ chi $2=0.000<\alpha=$ 0.05 , therefore, the authors reject $\mathrm{H} 0$ and apply Fixed Effects Model.

Table 6: Hausman test result

\begin{tabular}{ll}
$\mathrm{Chi}^{2}$ & 25.96 \\
Prob $>\mathrm{Chi}^{2}$ & 0.0005 \\
\hline
\end{tabular}

Source: Authors' calculation from the STATA 13.0 software

To test autocorrelation, the authors use Wooldridge test to test hypothesis $\mathrm{H} 0$ : there is no first - order autocorrelation. With significance level 5\%, Prob = $0.1524>0.05$, accept H0. Therefore, in this model, serial autocorrelation phenomenon does not exist.

To test Heterokedasticity, the authors use Wald test. The result is that $\mathrm{p}$-value $=0.000<0.05$, this model has unrestricted heterokedasticity. To overcome this phenomenon, this study carried out Feasible Generalized Least Squares method (FGLS).

Regression results from the FGLS model in Table 5 show that PROF, TANG, SIZE, LIQ factors have a negative influence on the capital structure of listed pharmaceutical - medical enterprises and the factor GRO has a positive influence on the debt-to-total asset ratio. Firm age (AGE) and pluralist executives (PLU) do not have statistical meaning, in other word, do not affect the capital structure.

The detailed regression model is written as follow:

$$
\begin{aligned}
& \text { TD }=1.5625-0.4619 * \text { PROF }-0.00433 * \text { TANG }- \\
& 0.0298 * \text { SIZE }+0.0335 * \text { GRO }-0.0977 * \text { LIQ }+\varepsilon
\end{aligned}
$$

\subsection{Discussion}

The beta coefficient of profitability (PROF) is -0.4619 which shows that profitability has a negative impact on financial leverage and hence, hypothesis $H 1$ is supported. This coefficient illustrates that when profit in the pharmaceutical industry increases 1 unit, the funding from debt decreases 0.4619 units. This is also the factor that has the strongest influence on the capital structure of enterprises. The negative relationship between profitability and debt ratio can be explained based on pecking order theory. When enterprises operate effectively, priority will be given to internal capital from retained earnings instead of borrowing to finance investment and production activities. In other words, the order of capital that enterprises prefer to use will be retained earnings, debt and finally the issuance of new shares.

The beta coefficient of tangible assets is -0.0298 indicates a negative impact of tangible assets on the financial leverage which means hypothesis $\mathrm{H} 2$ is not supported. If the fixed asset ratio of the enterprise increases to $1 \%$, the debt/total assets ratio of the enterprise will decrease by $2.98 \%$ when other factors are constant. According to the trade-off theory, firms with more fixed assets will find it easier to borrow because they use fixed assets as collateral. This will help creditors assess the risk of businesses lower and lend at a more affordable cost than without collateral. Therefore, when there are more fixed assets, enterprises also have more opportunities to use debt. This result is similar with the research findings of (Booth, Aivazian, Demirguc-Kunt, and Maksimovic, 2001); (Sayilgan, Karabacak, and Kucukkocaoglu, 2006); (Nguyen and Ramachandran, 2006); (Sheikh and Wang, 2011); (Imtiaz et al., 2016).

The beta coefficient of the size of the firms (SIZE) is -0.000393 which means that the size of the companies has a negative associated with debt ratio. This result is suitable with the pecking order theory, the study of (Titman and Wessels, 1988); (J. J. Chen, 2004) which showed that asymmetric information in large - sized companies is less than the small - sized ones because the big enterprises usually have the tendency to provide information for external investors. Therefore, they usually prefer using equity to debt. However, this finding means hypothesis $\mathrm{H} 3$ is not accepted.

Enterprises whose revenue growth rate increases to $1 \%$, the debt/total assets ratio will increase to $3.35 \%$, respectively, when other factors are constant. When businesses have many growth opportunities but internal capital from retained earnings is not enough to meet capital needs, enterprises will prioritize using debt instead of issuing new shares. Therefore, the higher the growth rate of the enterprise, the higher the debt ratio of the enterprise will be. The positive relationship between growth opportunity and debt ratio supports hypothesis $\mathrm{H} 4$ and is in line with the a variation of study of (Sayilgan et al., 2006); (Nguyen and Ramachandran, 2006); (Minh and Dung, 2015); (Vo, 2017).

Hypothesis H5 is supported because the coefficient of the liquidity ratio in the regression result is -0.0977 which points out that liquidity has the opposite impact on debt ratio. This correlation supports the predictions of pecking order theory that when looking for capital, firms usually do a favour of internal funding by retained 
earnings rather than using external funding. The similar finding was found in the researches of (Saeedi and Mahmoodi, 2011), (Saeed et al., 2014) and (De Jong et al., 2008).

Hypothesis $H 6$ and hypothesis $H 7$ are rejected because regression results are not significant at $\mathrm{p}<0.01, \mathrm{p}<0.05$, $\mathrm{p}<0.1$. It can be explained that pharmaceutical and medical enterprises when using loans are often afraid of problems such as cumbersome procedures, high interest rates and the demand of the firms whether they need to borrow capital or not. Hence, firm age and pluralist executives do not have statistical meaning

\section{CONCLUSION AND RECOMMENDATIONS}

This study identified the determinants affecting the capital structure of 23 listed pharmaceutical medical enterprises on Hanoi Stock Exchange and Ho Chi Minh City Stock Exchange by using the Pooled OLS, FEM, REM and FGLS regression method. Data is collected from financial statements and annual reports of listed pharmaceutical medical firms during the period from 2016 to 2020 . The regression model is used to test the effect of seven explanatory variables including profitability, tangible asset, firm size, growth opportunities, liquidity, firm age and pluralist executives to the ratio of total debt to total assets. Research results show that profitability, tangible assets, firm size and liquidity have a negative correlation with capital structure. In contrast, growth opportunities ratio has a positive relationship with capital structure. Firm age and pluralist executives do not have statistical meaning.

From the research findings, we give some recommendations for listed pharmaceutical - medical firms to have appropriate strategy for capital structure in order to maximize their value and profit as below:

Firstly, the listed enterprises need to proactively set up a department in charge of capital management. Capital management is an extremely important activity for businesses in the process before and after building the target capital structure. However, most enterprises have not yet established a specialized department in this field. The responsibility for planning the capital structure of a business is often delegated to the board of directors. Therefore, to be able to build and manage an effective capital structure, enterprises should set up a dedicated department to manage capital which is responsible for recommending changes to the operational plans if there is inconsistency or conflict between the ability to raise capital and the business's development plan and strategy.

Secondly, forms of capital mobilization need to be diversified. One of the important forms of capital mobilization that businesses should exploit is issuing corporate bonds that should be conducted widely and publicly and not limited to just a few ordinary investors. In particular, businesses should pay attention to introduce bonds to foreign investors. Many foreign investors, especially large, risk-tolerant investors, are very fond of corporate bonds of developing countries like Vietnam because the growth potential is still quite high and interest rates are low which also more attractive than developed countries.

For medical and pharmaceutical enterprises involved in import and export activities, it is necessary to take advantage of the forms of international trade financing such as discounting commercial papers, pledging valuable papers, letters of credit $(\mathrm{L} / \mathrm{C})$, factoring, etc. It should be noted that with the development scale of the import-export industry of medicine and pharmaceuticals in Vietnam and the speed of globalization in the field of import and export in general, the use of these financing vehicles will be an inevitable trend.

For businesses operating in the field of manufacturing medical equipment or pharmaceuticals that have a great need for investment in fixed assets, renting an asset will be an appropriate choice. In essence, leasing is also a form of credit with assets. The expertise of property leasing companies in the field of property investment will help businesses save time and costs when they want to borrow capital to increase fixed assets.

Thirdly, improve the quality of corporate governance. Businesses need to raise further awareness of the importance of appropriate governance, pay more attention to protecting the rights of shareholders and stakeholders, and increase public transparency, ensuring the responsibility of the Board of Directors in risk monitoring. Strong role of the supervisory board and internal audit department is a tool to help detect and improve weaknesses in the enterprise's management system. Members of the Supervisory Board must be independent members with appropriate qualities. Strengthening the role of chief financial officer (CFO) in corporate governance is vital. The accounting department is required to provide an integrated information system to store, monitor, and report the performance and financial position, and an internal control system to ensure the effective governance and fraud prevention.

\section{REFERENCES}

[1] Abor, J. (2007), "Corporate governance and financing decisions of Ghanaian listed firms", Corporate Governance: The international journal of business in society.

[2] Anh, N. T. and Huyen, L. T. H. (2015), "Determinants of Capital structure: Empirical evidence from Vietnamese listed construction companies", Journal of International Economics and Management, 76, 35-51.

[3] Anh, Đ. N. P. (2010), "Các nhân tố ảnh hưởng đến cấu trúc tài chính và hiệu quả tài chính: Tiếp cận theo phương pháp phân tích đường dẫn", Tạp chi khoa học và công nghệ, Đại học Đà Nã̃ng, 5, 14-24.

[4] Booth, L., Aivazian, V., Demirguc-Kunt, A., and 
Maksimovic, V. (2001), "Capital structures in developing countries", The Journal of Finance, 56, (1), 87-130.

[5] Chen, J., and Strange, R. (2005), "The determinants of capital structure: Evidence from Chinese listed companies", Economic change Restructuring, 38, (1), 11-35.

[6] Chen, J. J. (2004), "Determinants of capital structure of Chinese-listed companies", Journal of Business research, 57,(12), 1341-1351.

[7] De Jong, A., Kabir, R., and Nguyen, T. T. (2008), "Capital structure around the world: The roles of firm-and country-specific determinants", Journal of Banking Finance, 32,(9), 1954-1969.

[8] Donaldson, G. (1961). Corporate debt capacity: A study of corporate debt policy and the determination of corporate debt capacity. Washington, D.C: Beard Books, 2000.

[9] Fosberg, R. H. (2004), "Agency problems and debt financing: leadership structure effects", Corporate Governance: The international journal of business in society.

[10] Frank, M. Z., and Goyal, V. K. (2003), "Testing the pecking order theory of capital structure", Journal of Financial economics, 67, (2), 217-248.

[11] Gujarati, D. N., Porter, D. C., and Gunasekar, S. (2012). Basic econometrics: Tata McGraw-Hill Education.

[12] Hall, G., Hutchinson, P., and Michaelas, N. (2000), "Industry effects on the determinants of unquoted SMEs' capital structure", International journal of the economics of business, 7,(3), 297-312.

[13] Huang, S. G. H., and Song, F. M. (2006), "The determinants of capital structure: Evidence from China", China Economic Review, 17(1), 14-36.

[14] Imtiaz, F., Mahmud, K., and Mallik, A. (2016), "Determinants of capital structure and testing of applicable theories: Evidence from pharmaceutical firms of Bangladesh", International Journal of Economics Finance, 8, (3), 23-32.

[15] Jaradat, M. S. (2015), "Corporate governance practices and capital structure: A study with special reference to board size, board gender, outside director and CEO duality", International Journal of Economics, Commerce Management, 3, (5), 264-273.

[16] Jensen, M. C., and Meckling, W. H. (1976), "Theory of the firm: Managerial behavior, agency costs and ownership structure", Journal of Financial economics, 3,(4), 305-360.

[17] Kieschnick, R., and Moussawi, R. (2018), "Firm age, corporate governance, and capital structure choices", Journal of Corporate Finance, 48, 597-614.

[18] Kraus, A., and Litzenberger, R. H. (1973), "A state-preference model of optimal financial leverage", The journal of finance, 28,(4), 911-922.

[19] Minh, P. T., and Dung, N. T. (2015), "Factors influencing capital structure of Vietnam's real estate enterprises: a move from static to dynamic models", Journal of Economic Development (JED, Vol. 22 (4)), 76-91.

[20] Modigliani, F., and Miller, M. H. (1958), "The cost of capital, corporation finance and the theory of investment", The American economic review, 48, (3), 261-297.

[21] Modigliani, F., and Miller, M. H. (1963), "Corporate income taxes and the cost of capital: a correction", The American economic review, 53, (3), 433-443.

[22] Myers, S. C., and Majluf, N. S. (1984), "Corporate financing and investment decisions when firms have information that investors do not have", Journal of Financial economics, 13, (2), 187-221.

[23] Nguyen, T. D. K., and Ramachandran, N. (2006), "Capital structure in small and medium-sized enterprises: the case of Vietnam", ASEAN Economic bulletin, 192-211.

[24] Saeed, R., Munir, H. M., Lodhi, R. N., Riaz, A., and Iqbal, A. (2014), "Capital structure and its determinants: Empirical evidence from Pakistan's pharmaceutical firms", Journal of Basic Applied Scientific Research, 4, (2), 115-125.

[25] Saeedi, A., and Mahmoodi, I. (2011), "Capital structure and firm performance: Evidence from Iranian companies", International Research Journal of Finance Economics, 70, 20-29.

[26] Sayilgan, G., Karabacak, H., and Kucukkocaoglu, G. (2006), "The firm-specific determinants of corporate capital structure: Evidence from Turkish panel data", Investment Management Financial Innovations, 3, (3), 125-139.

[27] Sheikh, N. A., and Wang, Z. (2011), "Determinants of capital structure: An empirical study of firms in manufacturing industry of Pakistan", Managerial finance.

[28] Titman, S., and Wessels, R. (1988), "The determinants of capital structure choice", The journal of finance, 43, (1), 1-19.

[29] Vo, X. V. (2017), "Determinants of capital structure in emerging markets: Evidence from Vietnam", Research in International Business Finance, 40, 105-113.

[30] Wald, J. K. (1999), "How firm characteristics affect capital structure: an international comparison", Journal of Financial research, 22, (2), 161-187. 